\title{
ОСОБЕННОСТИ НУТРИТИВНОГО СТАТУСА КОМОРБИДНЫХ БОЛЬНЫХ
}

\author{
Дербенева С.А., Стародубова А.В. \\ ФГБУН «ФИЦ питания и биотехнологии», Москва
}

ЦЕЛЬ: изучить особенности нутритивного статуса пациентов с ожирением, осложненным развитием синдрома обструктивного апноэ сна (СОАС).

МАТЕРИАЛЫ И МЕТОДЫ: В отдеЛеНИИ Сердечно-СОсУдистой патологиИ КлиникИ ФГБУН «ФИЦ питания и биотехнологии» было обследовано 422 пациента с различной степенью ожирения, разделенные на три группы: I ст. ожирения ( $n=52)$, II степень ожирения $(\mathrm{n}=96)$, III степень ожирения $(\mathrm{n}=274)$. Учитывая низкую распространенность СОАС при ожирении I степени, в дальнейшее исследование были включены пациенты II и III степени ожирения. Проведена оценка пищевого статуса пациентов, включающая анализ фактического питания в домашних условиях, оценку параметров энергетического обмена, оценку лабораторных показателей крови. На основании результатов кардиореспираторного монирорирования диагностировалось наличие СОАС и степень его выраженности.

PEЗУЛЬТАТЫ: При анализе фактического питания пациентов исследуемых групп установлено, что питание пациентов с ожирением II и III ст. с СОАС характеризуется повышенной калорийностью рациона

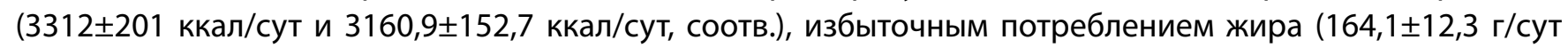

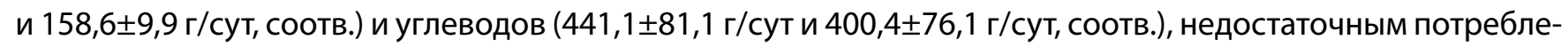

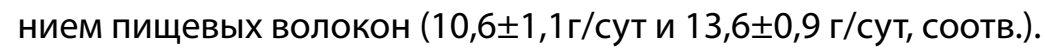

При анализе биохимических показателей крови во всех исследуемых группах выявлено повышение уровня триглицеридов (ТГ). При этом у пациентов с тяжелой ст. СОАС уровень ТГ достоверно $(p<0,05)$ превышал таковой в группе пациентов с СОАС легкой ст. Среди пациентов с ожирением III ст. уровень ТГ зафиксирован на достоверно более высоком уровне при наличии СОАС, чем в группе без СОАС $(p=0,019)$.

У пациентов с ожирением II и III ст. и СОАС зафиксирован достоверно $(p<0,05)$ более высокий уровень

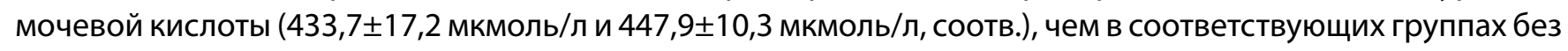
СОАС $(366,6 \pm 13,7$ мкмоль/л и 419,2 $\pm 7,86$ мкмоль/л).

У пациентов с ожирением III ст. и СОАС зафиксирован достоверно $(p=0,012)$ более высокий уровень

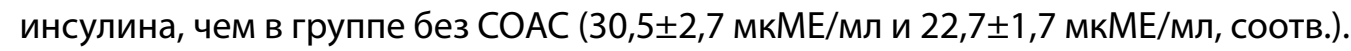

При исследовании показателей энергетического обмена установлено, что у пациентов с СОАС и ожирением II ст. в сравнении с пациентами с ожирением II ст. и без СОАС достоверно выше величина основного обмена (ОО) (2046 $\pm 138,0$ ккал/сут и 1678 75,6 ккал/сут, соотв., $\mathrm{p}=0,018)$ и скорость окисления угле-

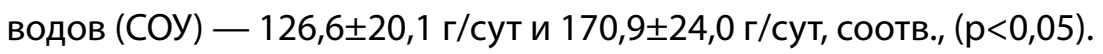

В группе пациентов с ожирением III ст. и СОАС показатели ОО также достоверно превышали соответ-

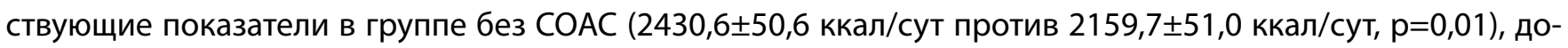

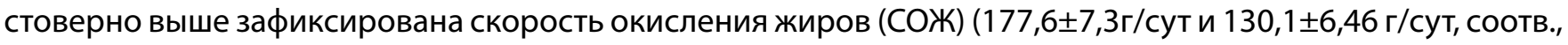
$\mathrm{p}=0,05)$.

Получены данные о достоверном увеличении СОЖ в группе пациентов с СОАС и III ст. ожирения по срав-

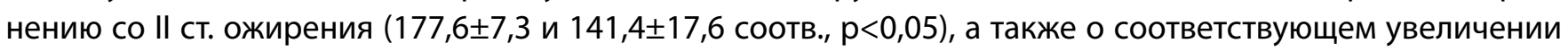
COУ $(146,1 \pm 7,3$ г/сут в группе с СОАС и ожирением III ст. и 126,6 20,1 г/сут в группе с СОАС и ожирением II CT., $p<0,05)$.

ВЫВоды: Ожирение в сочетании с СОАС сопровождается выраженными изменениями нутриметаболомного статуса пациентов, что обосновывает необходимость оптимизации и индивидуализации рационов питания данной категории больных с целью повышения ее эффективности.

Исследование проведено в рамках научной темы №0529-2019-0061. Источник финансирования — федеральный бюджет. 